Hughes, Michael, and David H. Demo (1989). Self-perceptions of Black Americans: Self-esteem and personal efficacy. American Journal of Sociology, 95, 132159.

Made available courtesy of University of Chicago Press: http://www.press.uchicago.edu

$* * *$ Reprinted with permission. No further reproduction is authorized without written permission from the University of Chicago Press.***

\title{
Self-Perceptions of Black Americans: Self-Esteem and Personal Efficacy ${ }^{1}$
}

\author{
Michael Hughes and David H. Demo \\ Virginia Polytechnic Institute and State University
}

This study examines the determinants of personal self-esteem, racial self-esteem, and personal efficacy in a 1980 national sample of black Americans. The findings show that the three dimensions are interrelated and each is anchored in interpersonal relations with family and friends. However, the three dimensions are produced by fundamentally different processes. Personal self-esteem is most strongly influenced by microsocial relations with family, friends, and community, while personal efficacy is generated through experiences in social statuses embedded in macrosocial systems of social inequality. We conclude that black self-esteem is insulated from systems of racial inequality, while personal efficacy is not, and suggest that this explains why black Americans have relatively high self-esteem but low personal efficacy. The belief that racial discrimination, rather than individual failure, accounts for low achievement among blacks is irrelevant to personal self-esteem and personal efficacy. In contrast, racial self-esteem is produced by a combination of education, interracial contact, and ideological processes.

Two major dimensions of self-perception known to be positively correlated are self-esteem and personal efficacy. Somewhat surprisingly, black Americans have relatively high self-esteem but relatively low personal efficacy. There is no widely accepted, empirically supported explanation for this apparent inconsistency. Most studies in this area have

\footnotetext{
${ }^{1}$ An earlier version of this paper was presented at the annual meeting of the American Sociological Association, Atlanta, Georgia, August 1988. We thank Clifford L. Broman, Walter R. Gove, Bradley R. Hertel, Carolyn J. Kroehler, Kay Oehler, James W. Michaels, Terance D. Miethe, Richard D. Shingles, Dale W. Wimberley, Michael R. Wood, and anonymous $A J S$ reviewers for comments on previous drafts. The data used in this paper were made available by the Inter-university Consortium for Political and Social Research. The data for the National Survey of Black Americans, 1979-1980, were originally collected by James S. Jackson and Gerald Gurin. Neither the collectors of the original data nor the consortium bears any responsibility for the analyses or interpretations presented here. Requests for reprints should be sent to Michael Hughes or David H. Demo, Department of Sociology, Virginia Polytechnic Institute and State University, Blacksburg, Virginia 24061.
}

(c) 1989 by The University of Chicago. All rights reserved. 0002-9602/90/9501-0004\$01.50 
focused on the issue of racial differences in self-esteem, paying particular attention to why black Americans do not generally have lower self-esteem than white Americans in spite of the fact that blacks experience low social status and economic and social discrimination in American society (see Porter and Washington [1979] and Wylie [1979] for reviews of this literature). These studies have also generated research questions about the processes involved in black self-concept development. In this article, we evaluate some of these questions by examining the determinants of black self-concept among respondents in a large national probability sample of black adults in the United States.

\section{LITERATURE REVIEW}

It is widely acknowledged that global self-esteem consists of two separate dimensions, one representing an individual's belief in his or her own virtue or moral worth, and the other indicating a sense of competence, efficacy, or personal control (Franks and Marolla 1976; Gecas 1982; Gecas and Schwalbe 1983). ${ }^{2}$ Though conceptually distinct, these two dimensions are strongly related, so that those with high personal efficacy also have high self-esteem (Franks and Marolla 1976; Gecas and Schwalbe 1983). Studies comparing blacks with whites have shown that if we use whites as a standard, blacks have relatively high self-esteem but low personal efficacy.

\section{Self-Esteem}

Although studies of black self-esteem have concentrated on the issue of racial differences (black vs. white), interpretations of these studies have yielded arguments concerning the process of self-esteem development among blacks. Many empirical studies show that blacks have self-esteem equal to or greater than that of whites ${ }^{3}$ (see, e.g., Gordon 1969; Simmons

\footnotetext{
${ }^{2}$ In this article, we will refer to the worth dimension of self-esteem as self-esteem (or as personal self-esteem where it must be clearly distinguished from racial self-esteem) and the efficacy dimension of self-esteem as personal efficacy. The studies of self-esteem cited here use the Rosenberg self-esteem scale or some comparable measure of selfworth, unless otherwise noted. As Gecas (1982) has pointed out, Rosenberg's scale measures essentially the worth dimension of self-esteem rather than the efficacy dimension.

${ }^{3}$ Studies of race and self-esteem exhibit a somewhat contradictory pattern (Wylie 1979; McCarthy and Yancey 1971; Rosenberg 1979; Porter and Washington 1979), with early studies arguing that being black is associated with poor self-esteem and later studies suggesting the opposite (for an analysis and debate over the meaning of these findings, see Adam [1978] and the commentaries by Simmons [1978] and Pettigrew [1978]).
} 
et al. 1978; Taylor and Walsh 1979; Rosenberg and Simmons 1972). Such findings appear to contradict three accepted theoretical principles of selfesteem: reflected appraisals, social comparisons, and self-attribution.

The principle of reflected appraisals (Cooley 1902; Rosenberg 1979), which indicates that a person's self-esteem is a product of how that person believes others see him, suggests that persons belonging to low-status groups will internalize the negative evaluation of society and as a consequence have low self-esteem. According to the social comparisons principle (Festinger 1954), self-esteem is, in part, a consequence of individuals' comparing themselves with others and making positive or negative selfevaluations. If blacks experience low levels of sociai and economic achievement in American society and recognize their status in comparison with whites, this should lead to low self-esteem. The principle of selfattribution (Bem 1967) indicates that self-esteem results from persons' observing their own overt behavior and characteristics, especially successes and failures. This principle suggests that as blacks pursue goals valued by the average American but are deterred by discrimination, their experience of themselves as failures produces low self-esteem.

Rosenberg (1981, pp. 604-7; 1979, pp. 157-75), however, argues that the straightforward application of these principles to predicting low selfesteem for black Americans involves the following erroneous assumptions: (1) the reflected appraisals important to black self-esteem are those of the wider, largely white society rather than those of family, friends, teachers, and classmates in the black community; (2) blacks use whites as the standard in social comparisons; and (3) blacks attribute individual responsibility for the low status accorded black people in American society to themselves instead of blaming systematic racial discrimination.

Reflected appraisals, social comparisons, and black self-esteem.-For negative attitudes of whites toward blacks to affect black self-esteem, blacks must be aware of these attitudes, accept them, consider them significant, and believe them to be personally relevant. Rosenberg (1979, pp. 157-70) suggests that in most cases these conditions are not met and thus black self-esteem is unaffected by the attitudes of whites. Instead, among black and white students, self-esteem is strongly related to the reflected appraisals of parents, friends, and teachers (Rosenberg and Simmons 1972), and these sources of self-esteem are more important for blacks than for whites (Hoelter 1982). ${ }^{4}$

For similar reasons, comparisons with whites do not contribute

\footnotetext{
${ }^{4}$ Further, because people selectively interact with others whom they perceive as having favorable attitudes toward them (Backman and Secord 1959, 1962; Dittes 1959), blacks who choose white friends are likely to choose those who hold more racially tolerant attitudes, and this should protect self-esteem.
} 
significantly to black self-esteem. Rosenberg and Simmons (1972) argue that because adolescents compare themselves with others in their own immediate interpersonal environments, black high school students, who are usually surrounded by other blacks, not whites, tend to compare themselves with other blacks. Krause's (1983) study supports this conclusion, showing that interracial contact among students is irrelevant to black self-esteem.

Studies that support the principles of reflected appraisals and social comparisons have used children and adolescents as subjects. However, the social contexts in which reflected appraisals and social comparisons occur are different for children than they are for adults. For example, Rosenberg and Pearlin (1978) demonstrate that during the adult years social class has an important influence on self-esteem because reflected appraisals and social comparisons are generated in social relations conditioned by institutional inequality. ${ }^{5}$ Although whites dominate in social class and socioeconomic relations, black adults, particularly those who participate in the labor force, may play roles in institutional settings where reflected appraisals of the dominant white society and social comparisons with whites may be important for black self-esteem.

Self-attribution and black self-esteem.- In the late 1960s and early 1970s sociologists argued that black Americans were keenly aware that discrimination and the structure of opportunities were responsible for the failure of the average black person to enjoy a life comparable with those of typical whites (see, e.g., Gurin et al. 1969). Presumably, this belief protected black self-esteem by enabling blacks to attribute blame for failure to the social system rather than to themselves as individuals (McCarthy and Yancey 1971; Porter and Washington 1979).

However, there is little empirical support for this mechanism of selfesteem enhancement. Taylor and Walsh (1979) found that while blacks blamed the system more than whites, controlling for system-blame did not affect the relationship between race and self-esteem. More important, they found that system-blame was not related to positive self-esteem for either blacks or whites and, in fact, was weakly associated with poor selfesteem. However, sampling limitations make it unclear how relevant these findings are to an understanding of the experience of most blacks.

Religion and black self-esteem.--Religion has not been mentioned in the literature as an important institutional source of self-esteem; most discussions focus on family, friendship, school, and work. However, because the black church is a central institution in a community that is

${ }^{5}$ Wylie (1979) has suggested that social class has a weak and inconsistent relationship with self-esteem. However, because race is a suppressor variable in the class/selfesteem relationship (Rosenberg and Pearlin 1978, p. 55), class may appear to be a weak predictor of self-esteem unless race is controlled. 
isolated from the larger society (Nelsen and Nelson 1975; Blackwell 1985), the social relationships emanating from the church and associated with religion may be an important source of black self-esteem, just as they are a source of psychological well-being (Ortega, Crutchfield, and Rushing 1983). Mays and Nicholson's ([1933] 1971) empirical study of the black church illustrates the role of this institution in generating reflected appraisals, social comparisons, and self-attributions that enhance black self-esteem.

The opportunity found in the Negro church to be recognized, and to be "somebody," has stimulated the pride and preserved the self-respect of many Negroes who would have been entirely beaten by life, and possibly completely submerged. Everyone wants to receive recognition and feel that he is appreciated. The Negro Church has supplied this need. A truck driver of average or more than ordinary qualities becomes the chairman of the deacon board. A hotel man of some ability is the superintendent of the Sunday church school of a rather important church. A woman who would be hardly noticed, socially or otherwise, becomes a leading woman in the missionary society. . . . [Mays and Nicholson 1971, p. 289]

Summary: Self-esteem.-In sum, the literature suggests the following should be true for black adults: (1) quality of relationships with family and friends is positively related to self-esteem, (2) social contact with whites is generally unimportant to self-esteem, and (3) religious involvement is an important source of self-esteem. It is unclear how social class and system-blame are related to self-esteem.

\section{Racial Self-Esteem}

Another factor prominently mentioned in the literature as being important in black self-esteem is ethnic pride, or what Porter and Washington (1979) call racial self-esteem. While studies done before 1970, most involving children, consistently reported that blacks generally had low racial self-esteem, studies done in the past two decades report an increasing tendency for black children to prefer their own racial group (Hraba and Grant 1970; Katz and Zalk 1974). This trend suggests a subcultural explanation for racial self-esteem - that the black-consciousness movement socialized black children and young adults into accepting new norms and values (Porter and Washington 1979) and identifying more strongly with their group (Krystall et al. 1970; Toomer 1975).

This trend is also consistent with relative-deprivation theory (Pettigrew 1964, 1967). According to this view, when the rising expectations of blacks in the 1950s and 1960s were not fulfilled, feelings of fraternal deprivation led to militancy and an associated ideology involving high racial self-esteem (Porter and Washington 1979). Empirical studies report 
that the most militant attitudes and highest ethnic pride are found in groups that combine high expectations and awareness of discrimination: the young, male, and middle class (Kronus 1971; Sampson and Milam 1975).

Though racial self-esteem is clearly important in its own right, most investigators predict that as racial self-esteem increases, personal selfesteem increases (Porter and Washington 1979, pp. 67-68), although estimates of the strength of this relationship vary (Rosenberg and Simmons 1972; Porter 1971; Gurin and Epps 1975). The most comprehensive study is Rosenberg's (1979, pp. 177-90) analysis of children and adolescents showing that group identification and pride have little bearing on personal self-esteem for racial or religious groups in contemporary America. This occurs largely because racial or religious identity is not as important as other identities. Unfortunately, the correlates of racial selfesteem have not been systematically examined among black adults.

Summary: Racial self-esteem.-In sum, the relatively small body of research on racial self-esteem suggests that the following should be true among black adults: (1) age and racial self-esteem are inversely related, (2) racial self-esteem is related to being male and being middle class, and (3) racial self-esteem has a positive relationship with personal self-esteem.

\section{Personal Efficacy}

Studies of race differences in personal efficacy find that blacks tend to score lower than whites (Coleman et al. 1966; Gordon 1969; Hunt and Hunt 1977). Evidence from surveys conducted in various years from 1958 to 1976 indicates that there was no change in the race difference in personal efficacy over this 18 -year period, which included the civil rights movement and improvement in the social status of black Americans (Converse et al. 1980, pp. 7-19). As noted above, given that personal efficacy and self-esteem are positively correlated, and given that blacks have relatively high self-esteem, the fact that blacks have relatively low personal efficacy is something of an anomaly. Two possible explanations have been prominently mentioned.

First, personal efficacy and self-esteem may be uncorrelated or only weakly related among blacks (Hulbary 1975, p. 113; Crain and Weisman 1972 , p. 81). If this were true, it would suggest that among blacks global self-esteem lacks an efficacy component and is largely a function of selfworth.

Second, low personal efficacy (i.e., high external control) among blacks may be a psychological reflection of low status resources and a recognition of widespread discrimination. "Feelings of external control may thus represent not a passive belief in chance or fate but instead system-blame, 
which indicates a healthy sensitivity to the real world" (Porter and Washington 1979, p. 65; see also Hulbary 1975, p. 113). Researchers have argued that blaming the system, a reflection of external control, may contribute to high personal self-esteem (Pettigrew 1967; Porter and Washington 1979), thus explaining why blacks have both relatively high selfesteem and relatively low personal efficacy. A serious problem with this argument is that personal efficacy is distinguishable from, and unrelated to, system-blame (Gurin et al. 1969, pp. 36-41; Hulbary 1975, p. 113), which is, in turn, unrelated to self-esteem (Taylor and Walsh 1979).

Nonetheless, personal efficacy among blacks could be a product of social and economic inequality, quite independent of system-blame. Gecas and Schwalbe (1983; Gecas 1982; Schwalbe 1985) persuasively argue that the experience of effective performance is the most important factor in the development of a sense of personal efficacy. Because the social contexts that are particularly conducive to efficacious activity are institutional in nature - part of the macrostructure of society-indicators of an individual's location in that macrostructure (specifically, social class and work) should be strong predictors of personal efficacy.

Summary: Personal efficacy. - The literature suggests that the following should be true among black adults: (1) personal efficacy and selfesteem are positively related, and (2) social class is a strong predictor of personal efficacy.

\section{THE PROBLEM}

The literature on self-concept among black Americans offers no unambiguous answer to why blacks have relatively high self-esteem but low personal efficacy. A serious problem with previous studies is that their data are largely from samples of children and adolescents or restricted samples of adults. Because these samples are not representative of black adults and because some important variables (e.g., work and social class variables) may not have much effect until adulthood, it is unclear how the generalizations derived from these samples apply to the adult black population of the United States.

Our purposes in this study are to evaluate the generalizations presented in the summary sections above, using a national sample of black Americans, and to apply our findings about how social processes influence black self-perceptions toward understanding why black Americans have relatively high self-esteem but low personal efficacy.

We hypothesize that black self-esteem is largely a product of interpersonal relations in the family and community and is not strongly affected by dimensions of institutional inequality. This would explain why black 
self-esteem is relatively high in spite of the fact that blacks experience discrimination and low social and economic status. An alternative hypothesis is that black self-esteem is dependent mostly on racial self-esteem or on blaming the system for low socioeconomic achievement.

We also hypothesize that personal efficacy among blacks is dependent on the experience of efficacious activity and is therefore strongly related to dimensions of institutional inequality such as occupational prestige, education, and income. Given the history of discrimination against blacks, this would explain why blacks have relatively low personal efficacy. The competing hypothesis is that personal efficacy is dependent on the degree of external control as reflected in perceptions of discrimination (i.e., system-blame).

\section{DATA AND METHODS}

\section{The Sample}

Data for this study come from the National Survey of Black Americans (NSBA) (Jackson and Gurin 1987). Jackson and Gurin (1987, p. i) provide the following sampling information: "The NSBA is a national probability household survey of 2,107 black Americans, 18 years of age and older, conducted in 1979 and 1980 . . . The 2,107 face to face household interviews were conducted by an all black, male and female professional interviewing staff, trained and supervised by the Survey Research Center, Institute for Social Research, The University of Michigan." The response rate was approximately $69 \%$. The sample contains a "disparity in the proportion of women to men and a slight tendency to underrepresent younger people of both sexes and to overrepresent older women" (Jackson and Gurin 1987, p. iv). Other details concerning the data set and sampling procedure may be found in Jackson and Gurin (1987, pp. ivii). The small sampling irregularities noted here do not affect the pattern of our findings. Analyses run within age and gender categories and those produced with a weighting scheme designed to correct for sampling errors regarding age and gender are substantively identical with the analyses presented below.

Because the processes responsible for self-concept formation occur over time, the optimal design would involve longitudinal data. Unfortunately, the NSBA is a cross-sectional study, and the results of our analysis should therefore be viewed with some caution. However, readers should also note that, with very few exceptions, the literature on self-concept formation is based on cross-sectional studies (Demo 1984) and that there are no large national samples of black adults from which self-perception data have been collected at different points in time. 


\section{Variables}

Dependent variables.-(a) Self-esteem: Our six-item self-esteem scale includes two items from Rosenberg's (1979) self-esteem scale: "I feel that I'm a person of worth," and "I feel I do not have much to be proud of." Two items are from the self-esteem scale used in the Monitoring the Future Project (Bachman and Johnston 1978): "I feel that I can't do anything right," and "I feel that my life is not very useful." Two additional items were included to form a scale measuring the worth dimension of personal self-esteem: "I am a useful person to have around," and "As a person I do a good job these days." Four response categories ranging from "almost always true" to "never true" were provided for each statement. In a factor analysis of all six items, two factors emerge, one of positively worded items and the other of negatively worded items. This is typical of self-esteem scales that have both positively and negatively worded items (Carmines and Zeller 1979, pp. 62-70) and reflects response styles to such items. Before summing the scale, we recoded the negative items so that all items were in the positive direction. The $\alpha$ reliability coefficient for this scale is .66.

(b) Personal efficacy: The NSBA asked four questions measuring respondents' feelings of self-control and confidence in managing their own lives. These are the most highly correlated items (Wright 1976, p. 107) in a commonly used scale of personal efficacy (see Robinson and Shaver [1969, pp. 102-5] for a brief discussion of the scale and its history and validity). This scale has four items, each with two responses: (1) "Do you think it's better to plan your life a good ways ahead, or would you say life is too much a matter of luck to plan ahead very far?" (2) "When you do make plans ahead, do you usually get to carry out things the way you expected, or do things usually come up to make you change your plans?" (3) "Have you usually felt pretty sure your life would work out the way you want it to, or have there been times you haven't been sure about it?" (4) "Some people feel they can run their lives pretty much the way they want to, others feel the problems of life are sometimes too big for them." The $\alpha$ reliability coefficient for this scale is .57. Wright (1976) has shown that this measure is distinct from political efficacy, personal trust, and political trust. Our own analysis (not shown) using the same factoranalytic strategy employed by Wright (1976, pp. 105-9) indicates that this measure of personal efficacy is empirically distinct from our measure of personal self-esteem.

(c) Racial self-esteem: The operationalization of racial self-esteem is not standardized. We operationalize racial self-esteem for blacks as the belief that most black people possess positive characteristics and do not possess negative characteristics. The measurement amounts to an overall evalua- 
tion of black people as a group. The question was worded: "How true do you think it is that most black people

?" The question was completed with the following characteristics: $(a)$ keep trying, $(b)$ love their families, $(c)$ are ashamed, $(d)$ are lazy, $(e)$ neglect their families, $(f)$ are lying and trifling, $(g)$ are hardworking, $(h)$ do for others, $(i)$ give up easily, $(j)$ are weak, $(k)$ are proud of themselves, $(l)$ are honest, $(m)$ are selfish, $(n)$ are strong. Responses were coded (1) true, (2) somewhat true, (3) a little true, and (4) not true at all. Responses were recoded so that all items were in the positive direction. The $\alpha$ reliability coefficient for this scale is .80 .

Social class and work variables.-(a) Socioeconomic status: As indicators of the respondent's location in the macrostructure of American society, we use years of education, personal income, and occupational prestige. The NSBA provides the 1970 census's three-digit occupation code. We assigned to each case the NORC and Duncan socioeconomic prestige score associated with the three-digit occupation codes (for details, see Featherman, Sobel, and Dickens 1975). We then calculated $z$-scores for both measures of occupational prestige and used each respondent's average score as his occupational prestige score. Analyses include this variable only for persons employed at the time of the interview.

(b) Job characteristics: Job security, expected mobility, self-perception of work quality, and job satisfaction also may have an effect on selfperception (Kohn and Schooler 1983; Mortimer and Lorence 1979). For employed respondents, we include indicators of the respondent's perceived chances of losing his job, perceived chances of being promoted, and self-rated job satisfaction. We also include an item measuring selfrated job performance that was asked of all respondents.

(c) Employment: As employment itself may contribute to positive selfevaluation, we include a dummy variable to distinguish those who have a current job from all others $(1=$ not employed $)$.

Family, friendships, and religion.--Research indicates that, as is the case for children, the quality of family relations is important to selfesteem among adults (Demo, Small, and Savin-Williams 1987). Because adults spend considerable amounts of time in extrafamilial contexts, however, it is also important to examine the nature and quality of their informal relationships with friends. The four-item factor-weighted scale contains two items assessing the closeness of and satisfaction with family relations and two items assessing the quality of family and friendship roles. ${ }^{6}$ Factor analysis extracted a single factor with an eigenvalue of

\footnotetext{
${ }^{6}$ An anonymous reviewer of a previous version of this paper raised two related questions about the appropriateness of including the two role items "Being a good friend" and "Taking care of your family's wants and needs" in the quality of family and friendship relations scale. First, although the items concerning closeness and satisfac-
} 
1.57 , accounting for $39.5 \%$ of the variance in the four items. Four response categories were provided for each question (factor loadings are in parentheses): (1) "Would you say your family members are very close in their feelings to each other, fairly close, not too close, or not close at all?" (.530); (2) "How satisfied are you with your family life, that is, the time you spend and the things you do with members of your family?" (.695); (3) "Given the chances you have had, how well have you done in taking care of your family's wants and needs?" (.685); (4) "Given the chances you have had, how well have you done at being a good friend?" (.587).

To measure religious involvement, we combined three items into one scale using factor analysis to weight each item. The factor analysis extracted a single factor with an eigenvalue of 1.90 , accounting for $63.3 \%$ of the variance in the three items. The items and the factor loadings for each item are as follows: (1) "How often do you usually attend religious services?" (.804); (2) "How religious would you say you are?" (.781); (3) "How often do you read religious books or other religious materials?" (.800).

Ethnicity and racial ideology variables. - (a) System-blame and interracial contact: Our measure of system-blame is an additive scale of two items. Respondents were asked to respond to two questions with two possible choices: (1) “In the United States, if black people don't do well in

tion with family life may be good measures of the quality of interpersonal relations, the two role items may not be and therefore may not belong in the scale. Second, the two role items may be measuring the same thing as some items in the self-esteem scale (e.g., "I am a useful person to have around"), and thus any relationship found between selfesteem and quality of family and friendship may be an artifact of measurement. We argue that the two items in question measure the quality of role relationships that are particularly important in organizing the interpersonal behaviors that affect self-esteem through reflected appraisal and social comparison processes. Empirically, we find that when items from both scales are included in the same factor analysis, the four items in the quality of family and friendship scale load on a single factor, distinct from the selfesteem scale items. We believe that the analyses here that use the four-item quality of family and friendship scale provide the best representation possible with these data of the effects of close interpersonal relations on self-esteem. We emphasize, however, that neither the pattern of findings nor the theoretical implications of the present study are dependent on including the two role-quality items, as we have done in our analyses. In analyses not presented here, we found the following: (1) when we entered the quality of family and friendship items in a set of regressions as separate variables and evaluated the effect of different blocks of theoretically relevant variables through the proportion of variance each contributed independently to the variance explained, this more cumbersome analysis proved to be substantively identical with that presented below, and (2) when we reduced the quality of family and friendship scale to two items by eliminating the items about being a good friend and meeting one's family's needs and performed regressions analogous to those below, we found the same theoretically significant patterns of findings, including significant $(P<.001)$ effects of the reduced two-item scale. 
life it is because: one, they don't work hard to get ahead, or two, they are kept back because of their race"; and (2) "In this country, if black people do not get a good education or job, it is because: one, they haven't had the same chances as whites in this country, or two, they have no one to blame but themselves." The correlation between the two items is .370. A high score indicates that discrimination (or the system) is blamed.

The measure of interracial contact indicates the level of involvement the respondent has had with white people over his lifetime. Respondents were asked to judge the racial composition of eight social settings in their lives: (1) grammar or elementary school, (2) junior high school, (3) high school, (4) college, (5) neighborhood while growing up, (6) present neighborhood, (7) church or place of worship usually attended, and (8) present workplace, if employed. Responses were coded (1) all blacks, (2) mostly blacks, (3) about half blacks, (4) mostly whites, and (5) almost all whites and were summed across the seven items. There are considerable missing data on these items because many respondents had not been involved in all the settings indicated; for example, some grew up in areas where junior high schools do not exist. Where appropriate, we replaced missing data with data regarding analogous settings from the same life-cycle stage.

(b) Black-consciousness variables: We also include two measures of black consciousness: black identity and black separatism. The measure of black identity used in the present study was developed by Broman, Neighbors, and Jackson (1988) for use in their study of racial group identification among black adults. Respondents were asked: "How close do you feel in your ideas and feelings about things to black people who are ?" The kinds of people asked about were $(a)$ poor, $(b)$ religious, $(c)$ young, $(d)$ middle class, $(e)$ working class, $(f)$ older, $(g)$ elected officials, and $(h)$ professional black people. This question yielded eight items, each coded (1) not close at all, (2) not too close, (3) fairly close, (4) very close. Scores were averaged for each respondent. The $\alpha$ reliability coefficient for the scale is .82. If responses were missing on three or fewer of the eight items, the mean response of the items with valid responses was entered for the missing data. Scale scores were then calculated by summing item scores for those respondents with sufficient data for inclusion in the analysis.

Regarding black separatism, a number of questions were asked concerning commitment to African culture and the degree to which blacks should confine some of their social relationships to other blacks. Respondents were asked if they agreed with the following: (1) black children should learn an African language, (2) blacks should always vote for black candidates when possible, (3) black women should not date white men, (4) black people should shop in black-owned shops whenever possible, 
(5) black men should not date white women, (6) black parents should give their children African names. Four responses were possible, ranging from "strongly disagree" to "strongly agree." Since the two questions on dating were very strongly correlated, they were combined into a single item by averaging the responses on these two. The resulting five items were averaged for each respondent. In a factor analysis these items load strongly on a single factor and yield an $\alpha$ reliability coefficient of .61. If responses were missing on two or fewer of the five items, the mean response on the items with valid responses for each respondent was entered for the missing data.

Control variables.-Age and gender are included as control variables in the analyses that appear below because some of the independent variables, particularly social class and work variables, are related to both age and gender.

\section{FINDINGS}

Regression analysis was used to evaluate the relative effects of various determinants of racial self-esteem, personal efficacy, and personal selfesteem. A complete matrix of means, standard deviations, and correlations among variables is presented in the Appendix.

\section{Racial Self-Esteem}

In table 1 we present zero-order correlations and regression analyses for racial self-esteem for all respondents and for those currently employed. Separate analyses are presented because some of the theoretically significant independent variables (i.e., occupational prestige of current job, chances of losing one's job, chances of being promoted, and job satisfaction) are relevant only for those who are currently employed. The first regression analysis includes all predictor variables, and a second regression analysis includes only variables that are significant at .05 or less in the original regression analysis. Not surprisingly, the most important predictors of racial self-esteem are the ethnicity and racial ideology variables. System-blame, black identity, black separatism, and interracial contact are all positively, and significantly, related to racial selfesteem in both regression analyses. Quality of family and friendship relations is significant in the analysis for all respondents, occupational prestige is significant among the employed, and education is significant in both analyses.

In sum, racial self-esteem is enhanced by black consciousness: systemblame, black identity, and black separatism. Also important are contact with whites, positive relationships with family and friends, education, 


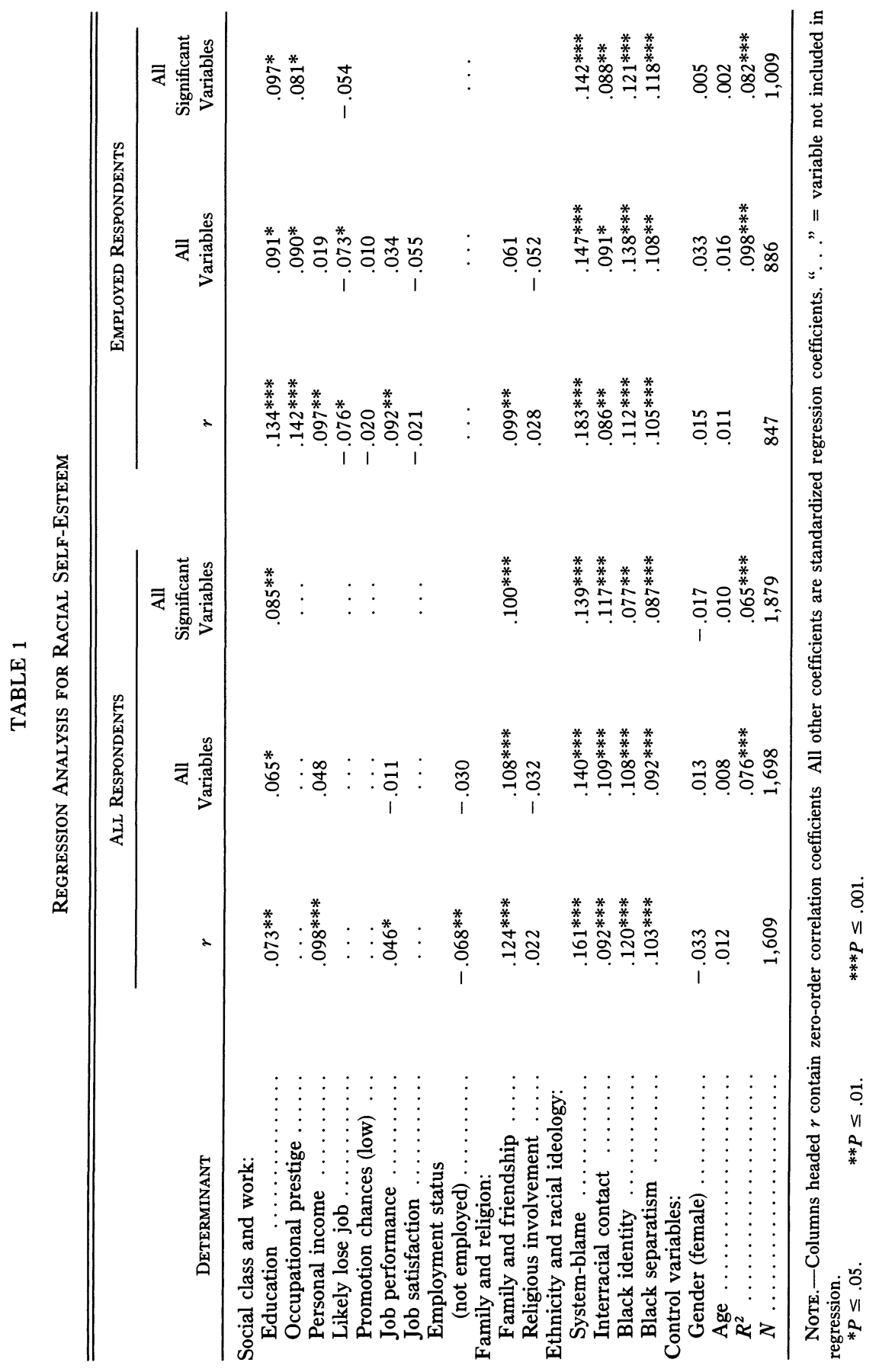


and occupational prestige. Though significant, the social class variables are not as strong as racial ideology variables. Religious involvement, age, gender, employment, and job characteristics have no independent relationships with racial self-esteem.

\section{Personal Efficacy}

Table 2 contains the analyses for personal efficacy. In the multiple regression analyses, the significant predictors among all respondents are education, personal income, quality of family and friendship relations, gender, and age. The same general pattern holds for the employed, for whom occupational prestige and self-rating of job performance are also significant, but gender is not.

Taken together, the measures of socioeconomic status are the most important predictors of personal efficacy relative to other variables. In the regression analyses, the ethnicity and racial ideology variables, religious involvement, and job characteristics are unrelated to personal efficacy. Overall, the findings indicate that higher socioeconomic status, better-quality relations with family and friends, being male, and being older are related to a greater sense of efficacy. When we add racial selfesteem to the analyses as an independent variable, we find that it is a significant predictor of personal efficacy and that its inclusion does not change the pattern of the findings.

\section{Self-Esteem}

Regression analyses for personal self-esteem are in table 3. Consistent with our predictions, the strongest influences on self-esteem among all respondents and among the currently employed are quality of family and friendship relations and religious involvement. Weaker but significant predictors for all respondents are education, personal income, self-rating of job performance, employment status, and being male. Among those currently employed, the only social class or work variable to exert a significant influence is self-rated job performance.

When we add racial self-esteem to the analysis, we find that it is a statistically significant predictor, and its inclusion does not change the pattern of findings. When we include personal efficacy in the analysis of all respondents, education and self-rated job performance become nonsignificant, but quality of family and friendship relations and religious involvement remain strong. In both analyses, personal efficacy is strongly related to self-esteem, even with controls for other important variables.

Notably, though black identity has a significant zero-order relationship with self-esteem, this correlation disappears in the regression analysis. 


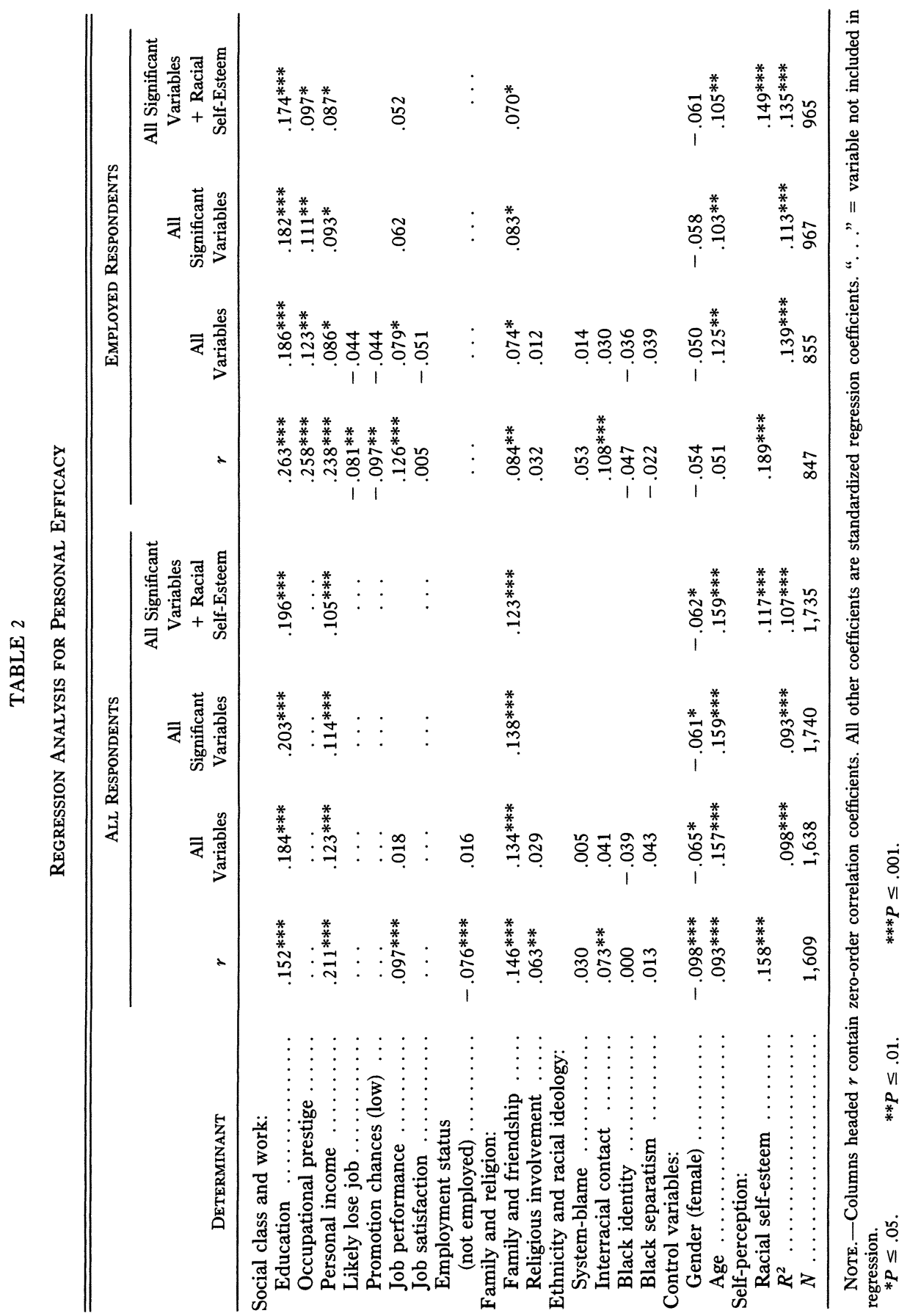




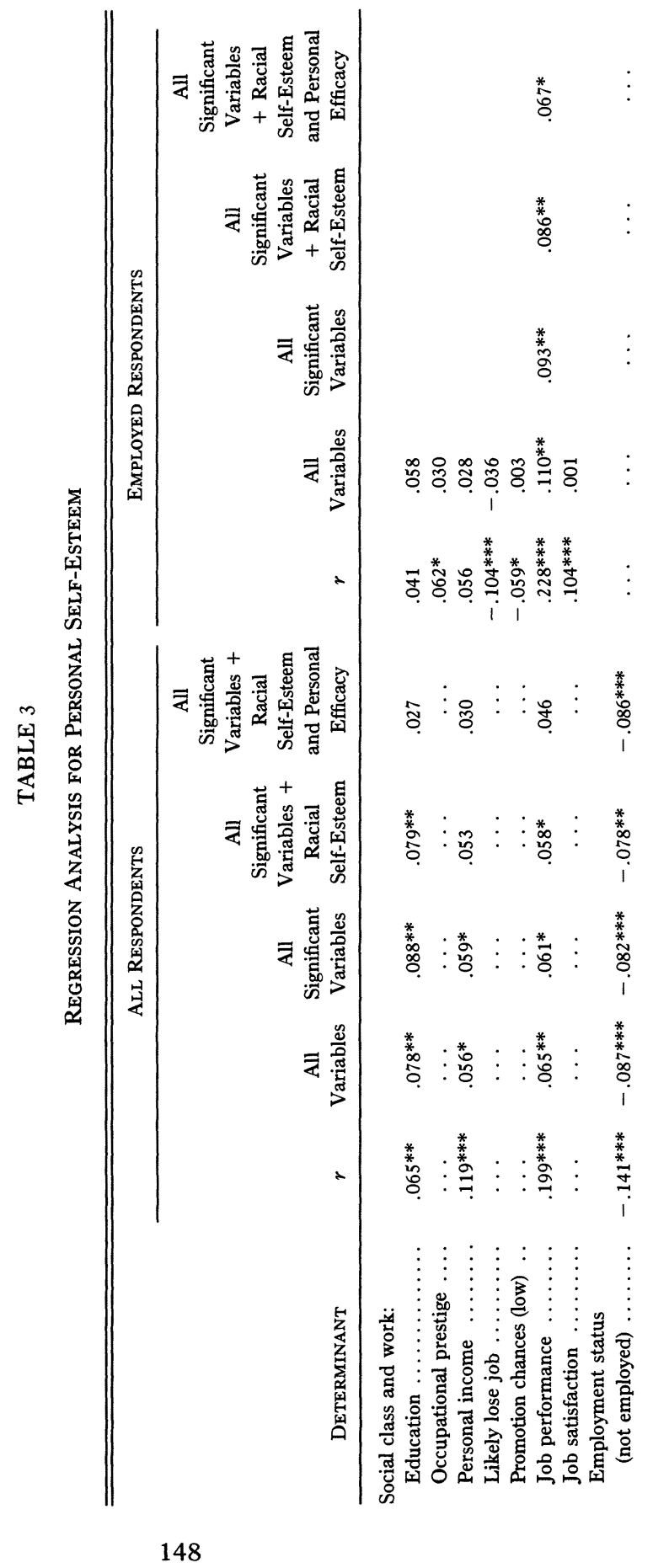




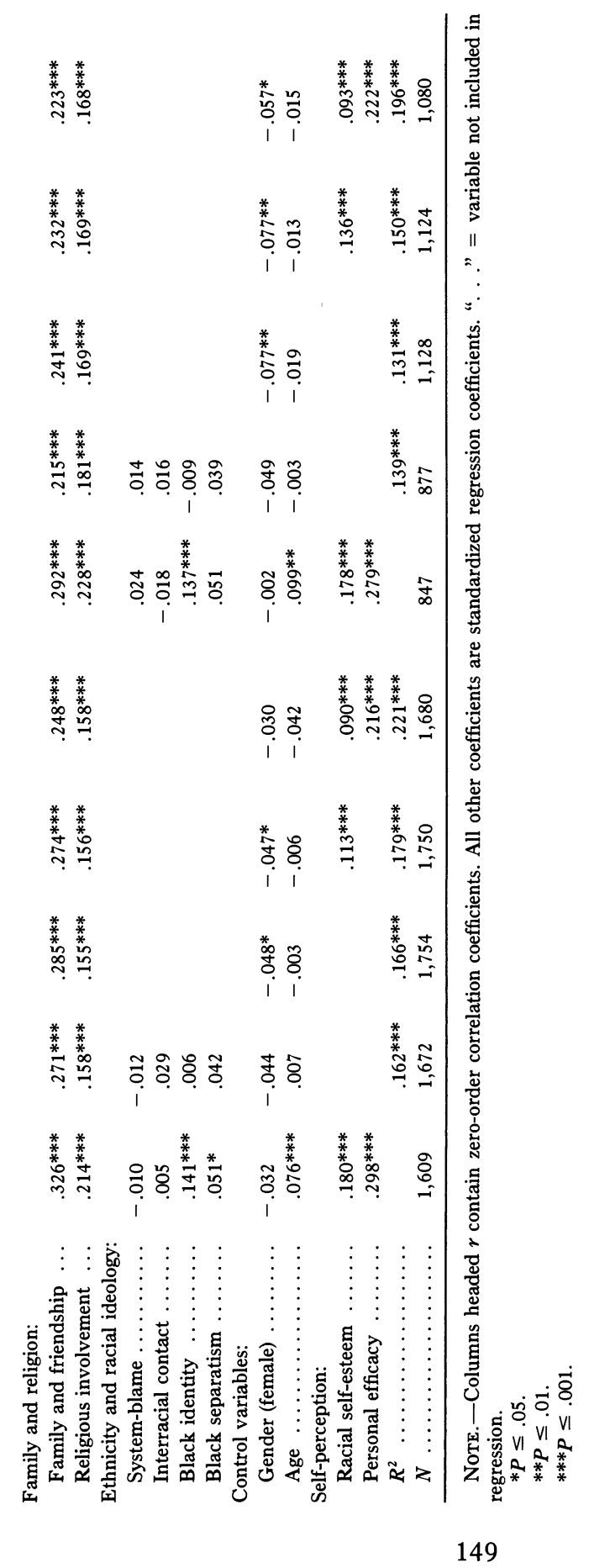


This happens because the correlations between black identity and religious involvement (.344) and between black identity and quality of family and friendship relations (.354) are substantial. Regressing self-esteem on religious involvement, quality of family and friendship relations, and black identity (analysis not shown), we found that the standardized regression coefficient for black identity reduced to -.009 , or essentially no effect. We conclude that religious involvement and quality of family and friendship relations produce both strong black identity and high selfesteem and that this explains the zero-order relationship between black identity and self-esteem.

\section{Interaction of System-Blame and Social Class}

Because of recent evidence indicating that the psychological centrality of social class for self-esteem increases with age (Demo and Savin-Williams 1983; Rosenberg and Pearlin 1978), we were surprised by the weak relationship between social class variables and self-esteem among black American adults, particularly among the currently employed. One plausible explanation for these findings is that black people may generally attribute individual success and failure to a discriminatory system beyond their control, thereby rendering social class irrelevant to black selfesteem. While our findings indicate that system-blame itself is not related to self-esteem, it may statistically interact with social class. For those who blame the system, social class should not be psychologically central to self-esteem and thus should be unrelated or even negatively related to self-esteem. For those who attribute responsibility to individuals, however, social class should be psychologically central to self-esteem, reflect success or failure in life, and thus be positively related to self-esteem.

To test this hypothesis, we constructed an interaction term by multiplying a socioeconomic-status index (a weighted index of education, personal income, and occupational prestige) by a dummy variable indicating individual versus system-blame $(1=$ blamed the system on either of the two variables in the system-blame index, and $0=$ blamed the individual). The system-blame dummy variable, the socioeconomic-status index, and this interaction term were entered in a regression analysis predicting selfesteem (results not shown). Other variables in the equation were quality of family and friendship relations, religious involvement, self-rated job performance, age, and gender. The regression coefficient for the interaction term was neither significant (at .05 or less) nor in the direction suggested above. Social class, we conclude, is not psychologically central to self-esteem among blacks, not even among those who believe that achievement is due to individual efforts. 


\section{DISCUSSION}

Our findings have a number of implications for theoretical discussions and research on self-concept formation among black Americans.

\section{Principles of Self-Esteem}

In theoretical terms, our findings strongly support two of Rosenberg's hypotheses (1979, pp. 157-75; 1981, pp. 604-7) concerning the application of self-esteem principles to black Americans. First, that the family/ friendship and religious-involvement variables are strong predictors of self-esteem and social class and work variables are weak ones indicates that the reflected appraisals important to black self-esteem are those of family, friends, and community members, not those of the wider world of institutional inequality dominated by whites. The importance of religion also provides strong empirical support for the positive influence of the black church postulated by Mays and Nicholson (1971) and Nelsen and Nelsen (1975). Second, consistent with Krause (1983), we found that interracial contact is not related to black self-esteem, supporting the idea that social comparisons with whites are not relevant to black self-esteem.

We found no support for the hypothesis that high black self-esteem is due to blaming discrimination for low socioeconomic achievement. This finding corroborates Taylor and Walsh (1979) and is particularly important given the widespread assumption that system-blaming leads to a more positive self-image among blacks (Myrdal 1944, p. 759; McCarthy and Yancey 1971, pp. 667-68; Porter and Washington 1979; Rosenberg 1981, p. 601; Shingles 1981, p. 78). We interpret these findings as indicating that system-blame represents a political belief concerning discrimination and individual responsibility that is not internalized in a way that is relevant for self-esteem.

\section{Psychological Centrality of Social Class}

Social class, shown by Rosenberg and Pearlin (1978) to be psychologically central to self-esteem for white male adults, appears not to be psychologically central to self-esteem among black adults. The socioeconomic status and work variables have weak or nonexistent relationships with selfesteem among blacks. When we examined the interaction between system-blame and socioeconomic status, we found no evidence that socioeconomic status had any relationship to self-esteem among those who believe that individual failure (and, by implication, success) is attributable to efforts of individuals. However, our analyses do not indicate that socio- 
economic status is irrelevant to black self-esteem. The weak but significant effect of education on self-esteem disappears when we enter personal efficacy. This occurs, we argue, because education produces greater personal efficacy, which is strongly related to self-esteem, not because it provides an intrinsic sense of self-worth.

In 1971, McCarthy and Yancey hypothesized that social class would have a weaker relationship with self-esteem among blacks than among whites (pp. 666, 668). Their argument was that middle-class blacks tend to accept white achievement values and therefore blame themselves for failures, while lower-class blacks can blame discrimination. Taken together, our finding that social class is not related to self-esteem among black adults and Rosenberg and Pearlin's (1978) finding of a significant relationship for white adult males provide some support for McCarthy and Yancey's hypothesis. However, the fact that system-blame is irrelevant in predicting self-esteem casts doubt on McCarthy and Yancey's explanation. Instead, we argue that the history of discrimination has had widespread effects throughout the entire black population, affecting the unconscious selection of dimensions on which self-esteem is based.

Historically, high levels of unemployment and racial discrimination have meant that the institutionalized work roles available to blacks have not been particularly stable. If it is true, as Zurcher (1977) argues, that when institutionalized roles are unstable they are less reliable sources of self-definition, then it is reasonable that social class and work would not be psychologically central to self-esteem among blacks. Studies have demonstrated that social roles that are not conducive to self-esteem are selectively devalued (Rosenberg 1979) and that "people gravitate toward opportunity structures that offer support for their self-conceptions" (Swann 1983, p. 36). Rather than being dependent on high socioeconomic attainment for a strong sense of self-worth, black self-esteem is anchored in interpersonal relations with extended families, friends, and churchbased social networks. If there are sharp declines in racial discrimination in employment and in the perceptions among black people that these disadvantages exist, then social class and work should become more important for black self-esteem.

\section{Racial Self-Esteem}

Our analysis of racial self-esteem contradicts the subcultural explanation that young blacks identify more closely with their ethnic group (Krystall et al. 1970; Toomer 1975). Apparently, recent socialization practices are no more or less effective than earlier practices in teaching group pride among blacks.

Not surprisingly, racial ideology variables that reflect cultural pro- 
cesses internal to the black community are the most important predictors of racial self-esteem. Quality of family and friendship relations also has a modest effect. However, racial self-esteem is not determined entirely by intraethnic, in-group processes. The effects of education and contact with whites suggest that integration into the wider society leads blacks to appreciate characteristics of their own ethnic group. If we assume that education and interracial contact lead to high achievement expectations, our findings support the relative-deprivation explanation proposed by Porter and Washington $(1979$, p. 58). Those with the highest racial selfesteem are those who combine high expectations with ethnic identity and the understanding that black achievement in the wider society has been blocked by racial discrimination.

Racial self-esteem is a significant predictor of both personal efficacy and self-esteem. Although other variables are more important, this finding supports Porter and Washington's (1979) position that, for black Americans, group pride is an important factor in self-perception.

\section{Personal Efficacy}

Personal efficacy is not associated with the belief that one's fate is controlled by a system that discriminates on the basis of race. Instead it is a product of one's location in the social order. These findings suggest, contrary to much recent speculation, that institutional inequality has important effects on black self-perceptions. Specifically, although social class is largely unrelated to personal self-esteem, inequality strongly influences personal efficacy by depriving blacks of opportunities that would enable them to feel efficacious (Franks and Marolla 1976). ${ }^{7}$ We interpret the strong association between social class variables and personal efficacy as support for Gecas and Schwalbe's (1983) hypothesis that the experience of effective performance is the most important factor in the development of personal efficacy. Discrimination in institutional life has largely relegated blacks to subordinate positions and excluded them from positions of power, resources, and contexts of action that afford individuals the best opportunities to experience themselves as powerful and autonomous. This is compelling support for Adam's (1978) assertion that "the effects of a racist social structure" have not simply faded away (p. 49). Informal family, friendship, and community social relations also are significantly

\footnotetext{
${ }^{7}$ It is also necessary to recognize the reciprocal nature of relationships between social structure and personality. It is certainly plausible, e.g., that among blacks personal efficacy influences educational and occupational attainment. Although the magnitude of such reciprocal effects is generally weaker than that of social structural effects on personality (House 1981; Kohn and Schooler 1983), the bidirectional quality of the processes must be recognized and provides an important focus for future research.
} 
related to personal efficacy but are less important than institutional inequality.

\section{CONCLUSION}

This study underscores the importance of researching black self-concept in a multidimensional framework. Racial self-esteem, personal efficacy, and personal self-esteem are interrelated, and, although each dimension is firmly anchored in the quality of relations with family and friends, the three dimensions are largely generated through different micro- and macrosocial processes that vary in their relations to institutional inequality. Personal self-esteem is generated in microprocesses in the black community that are insulated from institutional inequality. Racial self-esteem is partly generated by cultural and interpersonal processes internal to the black community, but it is also promoted by institutional inequality through education, interracial contact, and the perception that discrimination impedes the achievement of black people. Personal efficacy, produced by the personal experience of efficacious activity, is strongly affected by one's location in the macro-order of institutional inequality. The formal and informal processes of discrimination that exclude black people from positions of power and authority in American society also impair the development of personal efficacy.

Our findings strongly suggest that the apparent anomaly of high selfesteem coexisting with low personal efficacy among black Americans is understandable when we take account of the fact that inequality has little effect on black self-esteem but is an important determinant of personal efficacy. Perhaps it is time we turned away from the issue of self-esteem among black Americans and focused instead on personal efficacy, the social-psychological characteristic most affected by racial inequality in this society.

\section{REFERENCES}

Adam, Barry D. 1978. "Inferiorization and Self-Esteem." Social Psychology 41:47-53. Bachman, Jerald G., and L. D. Johnston. 1978. The Monitoring the Future Project: Design and Procedures. Ann Arbor: University of Michigan, Institute for Social Research.

Backman, C. W., and P. F. Secord. 1959. "The Effect of Perceived Liking on Interpersonal Attraction." Human Relations 12:379-84.

- 1962. "Liking, Selective Interaction, and Misperception in Congruent Interpersonal Relations." Sociometry 25:321-35.

Bem, Daryl J. 1967. "Self-Perception: An Alternative Interpretation of Cognitive Dissonance Phenomena." Psychological Review 74:183-200. 
Blackwell, James E. 1985. The Black Community: Diversity and Unity, 2d ed. New York: Harper \& Row.

Broman, Clifford L., Harold W. Neighbors, and James S. Jackson. 1988. "Racial Group Identification among Black Adults." Social Forces 67:146-58.

Carmines, Edward G., and Richard A. Zeller. 1979. "Reliability and Validity Assessment." Sage University Paper Series on Quantitative Applications in the Social Sciences, no. 07-017. Beverly Hills, Calif.: Sage.

Coleman, James, E. Campbell, J. McPartland, et al. 1966. Equality of Educational Opportunity. Washington, D.C.: Government Printing Office.

Converse, Philip, Jean D. Dotson, Wendy J. Hoag, and William H. McGee. 1980. American Social Attitudes Data Source Book: 1947-1978. Cambridge: Harvard University Press.

Cooley, Charles H. 1902. Human Nature and the Social Order. New York: Scribner's.

Crain, Robert L., and Carol Sachs Weisman. 1972. Discrimination, Personality, and Achievement. New York: Academic.

Demo, David H. 1984. "The Self over Time." Paper presented at the annual meeting of the American Sociological Association, San Antonio.

Demo, David H., and Ritch C. Savin-Williams. 1983. "Early Adolescent Self-Esteem as a Function of Social Class: Rosenberg and Pearlin Revisited." American Journal of Sociology 88:763-74.

Demo, David H., Stephen A. Small, and Ritch C. Savin-Williams. 1987. "Family Relations and the Self-Esteem of Adolescents and Their Parents." Journal of Marriage and the Family 49:705-15.

Dittes, J. E. 1959. "Attractiveness of Group as a Function of Self-Esteem and Acceptance by Group." Journal of Abnormal and Social Psychology 59:77-82.

Featherman, David L., Michael Sobel, and David Dickens. 1975. "A Manual for Coding Occupations and Industries into Detailed 1970 Categories and a Listing of 1970-Basis Duncan Socioeconomic and NORC Prestige Scores." Working paper 75-1. University of Wisconsin-Madison, Center for Demography and Ecology.

Festinger, Leon. 1954. "A Theory of Social Comparison Processes." Human Relations 7:117-40.

Franks, David D., and Joseph A. Marolla. 1976. "Efficacious Action and Social Approval as Interacting Dimensions of Self-Esteem: A Tentative Formulation through Construct Validation." Sociometry 39:324-41.

Gecas, Viktor. 1982. "The Self-Concept." Pp. 1-33 in Annual Review of Sociology, vol. 8. Palo Alto, Calif.: Annual Reviews.

Gecas, Viktor, and Michael L. Schwalbe. 1983. "Beyond the Looking-Glass Self: Social Structure and Efficacy-based Self-Esteem." Social Psychology Quarterly 46:77-88.

Gordon, Chad. 1969. Looking Ahead. Washington, D.C.: American Sociological Association.

Gurin, P., and E. Epps. 1975. Black Consciousness, Identity, and Achievement. New York: Wiley.

Gurin, P., G. Gurin, R. Lao, and M. Beattie. 1969. "Internal/External Control and the Motivational Dynamics of Negro Youth." Journal of Social Issues 25:29-53.

Hoelter, Jon W. 1982. "Race Differences in Selective Credulity and Self-Esteem." Sociological Quarterly 23:527-37.

House, James S. 1981. "Social Structure and Personality." Pp. 525-61 in Social Psychology: Sociological Perspectives, edited by Morris Rosenberg and Ralph H. Turner. New York: Basic.

Hraba, J., and G. Grant. 1970. "Black Is Beautiful: A Reexamination of Racial Preference and Identification." Journal of Personality and Social Psychology 16:398-402. 
Hulbary, William. 1975. "Race, Deprivation, and Adolescent Self-Image." Social Science Quarterly 56:105-14.

Hunt, Janet G., and Larry L. Hunt. 1977. "Racial Inequality and Self-Image: Identity Maintenance and Identity Diffusion." Sociology and Social Research 61:539-59.

Jackson, James S., and Gerald Gurin. 1987. National Survey of Black Americans, 1978-80 (machine readable codebook). Ann Arbor, Mich.: Inter-university Consortium for Political and Social Research, Institute for Social Research.

Katz, P., and S. Zalk. 1974. "Doll Preferences: An Index of Racial Attitudes." Journal of Educational Psychology 66:663-68.

Kohn, Melvin L., and Carmi Schooler. 1983. Work and Personality: An Inquiry into the Impact of Social Stratification. Norwood, N.J.: Ablex.

Krause, Neal. 1983. "The Racial Context of Black Self-Esteem." Social Psychology Quarterly 46:98-107.

Kronus, S. 1971. The Black Middle Class. Columbus, Ohio: Merrill.

Krystall, E., N. Friedman, G. Howze, and E. Epps. 1970. "Attitudes toward Integration and Black Consciousness: Southern Negro High-School Students and Their Mothers." Phylon 31:104-13.

McCarthy, J. D., and W. L. Yancey. 1971. "Uncle Tom and Mr. Charlie: Metaphysical Pathos in the Study of Racism and Personal Disorganization." American Journal of Sociology 76:648-72.

Mays, Benjamin E., and Joseph W. Nicholson. (1933) 1971. "The Genius of the Negro Church." Pp. 287-91 in The Black Church in America, edited by Hart M. Nelsen, Raytha L. Yokley, and Ann K. Nelsen. New York: Basic.

Mortimer, Jeylan T., and Jon Lorence. 1979. "Occupational Experience and the SelfConcept: A Longitudinal Study." Social Psychology Quarterly 42:307-23.

Myrdal, Gunnar. 1944. An American Dilemma. New York: Harper.

Nelsen, Hart M., and Anne Kusener Nelsen. 1975. Black Church in the Sixties. Lexington: University Press of Kentucky.

Ortega, Suzanne T., Robert D. Crutchfield, and William A. Rushing. 1983. "Race Differences in Elderly Personal Well-Being." Research on Aging 5:101-18.

Pettigrew, Thomas F. 1964. Profile of the Negro American. Princeton, N.J.: Van Nostrand.

- 1967. "Social Evaluation Theory: Convergences and Applications." Nebraska Symposium on Motivation 15:241-311.

- 1978. "Placing Adam's Argument in a Broader Perspective." Social Psychology 41:58-61.

Porter, Judith R. 1971. Black Child, White Child: The Development of Racial Attitudes. Cambridge: Harvard University Press.

Porter, Judith R., and Robert E. Washington. 1979. "Black Identity and Self-Esteem: A Review of Studies of Black Self-Concept, 1968-1978." Pp. 53-74 in Annual Review of Sociology, vol. 5. Palo Alto, Calif.: Annual Reviews.

Robinson, John P., and Phillip R. Shaver. 1969. Measures of Social Psychological Attitudes. Ann Arbor: University of Michigan, Institute for Social Research.

Rosenberg, Morris, 1979. Conceiving the Self. New York: Basic. . 1981. "The Self-Concept: Social Product and Social Force." Pp. 593-624 in Social Psychology: Sociological Perspectives, edited by Morris Rosenberg and Ralph H. Turner. New York: Basic.

Rosenberg, Morris, and Leonard Pearlin. 1978. "Social Class and Self-Esteem among Children and Adults." American Journal of Sociology 84:53-77.

Rosenberg, Morris, and Roberta G. Simmons. 1972. Black and White Self-Esteem: The Urban School Child. Rose Monograph series. Washington, D.C.: American Sociological Association.

Sampson, W., and V. Milam. 1975. "The Intraracial Attitudes of the Black MiddleClass: Have They Changed?" Social Problems 23:153-65. 
Schwalbe, Michael L. 1985. "Autonomy in Work and Self-Esteem." Sociological Quarterly 26:519-35.

Shingles, Richard D. 1981. "Black Consciousness and Political Participation: The Missing Link." American Political Science Review 75:76-91.

Simmons, Roberta G. 1978. "Blacks and High Self-Esteem: A Puzzle." Social Psychology 41:54-57.

Simmons, Roberta G., Leslie Brown, Diane Mitsch Bush, and Dale A. Blyth. 1978. "Self-Esteem and Achievement of Black and White Adolescents." Social Problems 26:86-96.

Swann, William B., Jr. 1983. "Self-Verification: Bringing Social Reality into Harmony with the Self." Pp. 33-66 in Psychological Perspectives on the Self, vol. 2. Edited by Jerry Suls and Anthony G. Greenwald. Hillsdale, N.J.: Erlbaum.

Taylor, Marylee C., and Edward J. Walsh. 1979. "Explanations of Black Self-Esteem: Some Empirical Tests." Social Psychology Quarterly 42:242-53.

Toomer, J. 1975. "Beyond Being Black: Identification Alone Is Not Enough." Journal of Negro Education 44:184-99.

Wright, James D. 1976. The Dissent of the Governed: Alienation and Democracy in America. New York: Academic.

Wylie, Ruth. 1979. The Self-Concept, rev. ed. Vol. 2: Theory and Research on Selected Topics. Lincoln: University of Nebraska Press.

Zurcher, Louis A., Jr. 1977. The Mutable Self: A Self-Concept for Social Change. Beverly Hills, Calif.: Sage. 
TABLE A1

Correlations, Means, and Standard Deviations

\begin{tabular}{|c|c|c|c|c|}
\hline & 1 & 2 & 3 & 4 \\
\hline 1. Education $\ldots \ldots \ldots \ldots \ldots \ldots \ldots$ & 1.000 & $.586 * * *$ & $.350 * * *$ & -.031 \\
\hline 2. Occupational prestige $\ldots \ldots \ldots$. & $\ldots$ & 1.000 & $.347 * * *$ & -.034 \\
\hline 3. Personal income $\ldots \ldots \ldots \ldots \ldots$ & $.382 * * *$ & $\ldots$ & 1.000 & $-.082 * *$ \\
\hline 4. Likely lose job ............ & $\ldots$ & . . & $\ldots$ & 1.000 \\
\hline 5. Promotion chances (low) ...... & $\ldots$ & $\ldots$ & $\ldots$ & $\ldots$ \\
\hline 6. Job performance $\ldots \ldots \ldots \ldots \ldots$ & -.029 & $\cdots$ & $.078 * * *$ & $\cdots$ \\
\hline 7. Job satisfaction $\ldots \ldots \ldots \ldots \ldots$ & $\ldots$ & $\ldots$ & $\ldots$ & . \\
\hline 8. Employment status & & & & \\
\hline (not employed) $\ldots \ldots \ldots \ldots \ldots$ & $-.316^{* * *}$ & $\ldots$ & $-.406^{* * *}$ & $\cdots$ \\
\hline 9. Family and friendship $\ldots \ldots \ldots$ & $-.128 * * *$ & $\ldots$ & -.011 & . . \\
\hline 10. Religious involvement $\ldots \ldots \ldots$ & $-.122 * * *$ & $\ldots$ & $-.114 * * *$ & $\ldots$ \\
\hline 11. System-blame $\ldots \ldots \ldots \ldots \ldots$ & .019 & $\ldots$ & .021 & $\ldots$ \\
\hline 12. Interracial contact $\ldots \ldots \ldots \ldots \ldots$ & $.360 * * *$ & $\ldots$ & $.242 * * *$ & $\ldots$ \\
\hline 13. Black identity $\ldots \ldots \ldots \ldots \ldots$ & $-.270 * * *$ & $\ldots$ & $-.154 * * *$ & $\ldots$ \\
\hline 14. Black separatism $\ldots \ldots \ldots \ldots \ldots$ & $-.242 * * *$ & $\ldots$ & $-.114^{* * *}$ & $\ldots$ \\
\hline 15. Gender (female) $\ldots \ldots \ldots \ldots \ldots$ & .016 & $\ldots$ & $-.335 * * *$ & $\ldots$ \\
\hline 16. Age $\ldots \ldots \ldots \ldots \ldots \ldots \ldots \ldots$ & $-.489 * * *$ & $\ldots$ & $-.054 * * *$ & $\ldots$ \\
\hline 17. Racial self-esteem $\ldots \ldots \ldots \ldots \ldots$ & $.073^{* *}$ & $\ldots$ & $.098 * * *$ & $\cdots$ \\
\hline 18. Personal efficacy $\ldots \ldots \ldots \ldots \ldots$ & $.152 * * *$ & $\ldots$ & $.211 * * *$ & $\ldots$ \\
\hline 19. Personal self-esteem $\ldots \ldots \ldots \ldots$ & $.065^{* *}$ & $\cdots$ & $.119 * * *$ & $\ldots$ \\
\hline Mean & 11.048 & $\ldots$ & $8,046.92$ & . \\
\hline SD & 3.344 & $\ldots$ & $7,376.65$ & $\cdots$ \\
\hline
\end{tabular}

TABLE A1 (Continued)

\begin{tabular}{|c|c|c|c|c|}
\hline & 12 & 13 & 14 & 15 \\
\hline 1. Education $\ldots \ldots \ldots \ldots \ldots \ldots$ & $.302 * * *$ & $-.274 * * *$ & $-.212 * * *$ & $.070 *$ \\
\hline 2. Occupational prestige ........ & $.254 * * *$ & $-.181^{* * *}$ & $-.160 * * *$ & $.072 *$ \\
\hline 3. Personal income $\ldots \ldots \ldots \ldots \ldots$ & $.233 * * *$ & $-.158^{* * *}$ & $-.104 * * *$ & $-.313 * * *$ \\
\hline 4. Likely lose job ............... & .004 & -.007 & .025 & -.045 \\
\hline 5. Promotion chances (low) $\ldots \ldots \ldots$ & $-.067 *$ & -.005 & .033 & $.070^{*}$ \\
\hline 6. Job performance $\ldots \ldots \ldots \ldots \ldots$ & $-.069 *$ & $.204 * * *$ & .002 & .027 \\
\hline 7. Job satisfaction $\ldots \ldots \ldots \ldots \ldots$ & -.055 & $207 * * *$ & -.007 & .043 \\
\hline $\begin{array}{l}\text { 8. Employment status } \\
\text { (not employed) } \ldots \ldots \ldots \ldots \ldots \ldots\end{array}$ & & & $\ldots$ & \\
\hline 9. Family and friendship $\ldots \ldots \ldots$ & $-.125 * * *$ & $.328^{* * *}$ & $.097 * *$ & .056 \\
\hline 10. Religious involvement $\ldots \ldots \ldots$ & $-.101 * *$ & $.347 * * *$ & .045 & $.195 * * *$ \\
\hline 11. System-blame $\ldots \ldots \ldots \ldots \ldots \ldots$ & -.023 & -.022 & $.112 * * *$ & -.039 \\
\hline 12. Interracial contact $\ldots \ldots \ldots \ldots \ldots$ & 1.000 & $-.258 * * *$ & $-.216^{* * *}$ & -.001 \\
\hline 13. Black identity $\ldots \ldots \ldots \ldots \ldots \ldots$ & $-.237 * * *$ & 1.000 & $.259 * * *$ & -.005 \\
\hline 14. Black separatism $\ldots \ldots \ldots \ldots \ldots$ & $-.210^{* * *}$ & $.287 * * *$ & 1.000 & $-.060 *$ \\
\hline 15. Gender (female) $\ldots \ldots \ldots \ldots \ldots$ & $-.051^{*}$ & -.014 & -.039 & 1.000 \\
\hline 16. Age $\ldots \ldots \ldots \ldots \ldots \ldots \ldots$ & $-.286 * * *$ & $.288^{* * *}$ & $.161 * * *$ & -.010 \\
\hline 17. Racial self-esteem $\ldots \ldots \ldots \ldots \ldots$ & $.092 * * *$ & $.120 * * *$ & $.103 * * *$ & -.033 \\
\hline 18. Personal efficacy $\ldots \ldots \ldots \ldots \ldots$ & $.073 * *$ & .000 & .013 & $-.098 * * *$ \\
\hline 19. Personal self-esteem $\ldots \ldots \ldots \ldots$ & .005 & $.141^{* * *}$ & $.051^{*}$ & -.032 \\
\hline Mean $\ldots \ldots \ldots \ldots \ldots \ldots \ldots \ldots$ & 1.927 & 3.358 & 2.971 & .617 \\
\hline SD $\ldots \ldots \ldots \ldots \ldots \ldots \ldots \ldots \ldots$ & .720 & .501 & .714 & .486 \\
\hline
\end{tabular}

Note.-Data presented below the diagonal are for all respondents $(N=1,609)$; those above the diagnonal are for currently employed respondents $(N=847)$. Missing data were deleted listwise.

$* P \leq .05$.

$* * P \leq .01$.

$* * * P \leq .001$. 


\begin{tabular}{|c|c|c|c|c|c|c|}
\hline 5 & 6 & 7 & 8 & 9 & 10 & 11 \\
\hline$-.150 * * *$ & -.019 & $-.136 * * *$ & $\ldots$ & $-.123^{* * *}$ & -.051 & $.057^{*}$ \\
\hline$-.210 * * *$ & $.068^{*}$ & .018 & $\ldots$ & $-.063 *$ & -.010 & $.059 *$ \\
\hline$-.149 * * *$ & -.004 & .013 & $\ldots$ & -.035 & $-.078^{*}$ & $.064 *$ \\
\hline $.102 * * *$ & $-.118^{* * *}$ & $-.206 * * *$ & $\ldots$ & $-.158 * * *$ & $-.067 *$ & .036 \\
\hline 1.000 & $-.105 * * *$ & $-.261 * * *$ & $\ldots$ & $-.086 * *$ & -.048 & $.065^{*}$ \\
\hline$\ldots$ & 1.000 & $.220 * * *$ & $\ldots$ & $.455 * * *$ & $.136 * * *$ & -.003 \\
\hline$\ldots$ & $\ldots$ & 1.000 & $\ldots$ & $.261 * * *$ & $.150 * * *$ & $-.073^{*}$ \\
\hline$\cdots$ & $-.088 * * *$ & $\cdots$ & 1.000 & $\cdots$ & $\cdots$ & $\cdots$ \\
\hline$\cdots$ & $.373 * * *$ & $\cdots$ & .017 & 1.000 & $.206 * * *$ & -.008 \\
\hline$\ldots$ & $.190 * * *$ & $\ldots$ & .037 & $.266^{* * *}$ & 1.000 & .018 \\
\hline$\ldots$ & -.011 & $\ldots$ & .021 & -.011 & -.002 & 1.000 \\
\hline$\ldots$ & $-.083 * * *$ & $\ldots$ & $-.184 * * *$ & $-.148 * * *$ & $-.156 * * *$ & -.019 \\
\hline . . & $.178 * * *$ & . . & $.049 *$ & $.354 * * *$ & $.344 * * *$ & .026 \\
\hline$\ldots$ & .037 & $\ldots$ & $.082 * * *$ & $.114^{* * *}$ & $.067 * *$ & $.129 * * *$ \\
\hline$\ldots$ & -.009 & $\cdots$ & $.156^{* * *}$ & $.049 *$ & $.208 * * *$ & $-.042 *$ \\
\hline$\ldots$ & $.185^{* * *}$ & $\ldots$ & $.215^{* * *}$ & $.264 * * *$ & $.372 * * *$ & $.047 *$ \\
\hline . & $.046^{*}$ & $\cdots$ & $-.068 * *$ & $.124 * * *$ & .022 & $.161^{* * *}$ \\
\hline$\ldots$ & $.097 * * *$ & $\cdots$ & $-.076^{* * * *}$ & $.146^{* * * *}$ & $.063 * *$ & .030 \\
\hline$\ldots$ & $.199 * * *$ & $\cdots$ & $-.141^{* * *}$ & $.326^{* * * *}$ & $.214^{* * *}$ & -.010 \\
\hline$\ldots$ & 4.620 & $\cdots$ & .405 & -.009 & .001 & 1.191 \\
\hline$\ldots$ & .640 & $\ldots$ & .491 & .980 & .983 & .810 \\
\hline
\end{tabular}

\begin{tabular}{|c|c|c|c|c|c|}
\hline 16 & 17 & 18 & 19 & Mean & $\mathrm{SD}$ \\
\hline$-.338 * * *$ & $.134^{* * *}$ & $.263^{* * *}$ & .041 & 11.968 & 2.799 \\
\hline$-.158 * * *$ & $.142 * * *$ & $.258 * * *$ & $.062 *$ & .186 & .995 \\
\hline $.098 * *$ & $.097 * *$ & $.238^{* * *}$ & .056 & $10,713.11$ & $7,697.65$ \\
\hline$-.088 * *$ & $-.076 *$ & $-.081 * *$ & $-.104 * * *$ & 1.834 & .939 \\
\hline $.163 * * *$ & -.020 & $-.097 * *$ & $-.059 *$ & 2.582 & 1.161 \\
\hline $.150 * * *$ & $.092 * *$ & $.126 * * *$ & $.228 * * *$ & 4.649 & .527 \\
\hline $.252 * * *$ & -.021 & .005 & $.104 * * *$ & 3.168 & .834 \\
\hline$\cdots$ & $\cdots$ & $\cdots$ & $\cdots$ & $\cdots$ & $\cdots$ \\
\hline $.221 * * *$ & $.099 * *$ & $.084 * *$ & $.292 * * *$ & -.036 & .946 \\
\hline $.295 * * *$ & .028 & .032 & $.228^{* * *}$ & -.033 & .995 \\
\hline .047 & $.183 * * *$ & .053 & .024 & 1.175 & .818 \\
\hline$-.183^{* * *}$ & $.086 * *$ & $.108 * * *$ & -.018 & 2.025 & .690 \\
\hline $.313 * * *$ & $.112 * * *$ & -.047 & $.137 * * *$ & 3.331 & .483 \\
\hline $.103 * * *$ & $.105 * * *$ & -.022 & .051 & 2.906 & .680 \\
\hline .019 & .015 & -.054 & -.002 & .549 & .498 \\
\hline 1.000 & .011 & .051 & $.099 * *$ & 38.615 & 13.747 \\
\hline .012 & 1.000 & $.189 * * *$ & $.178^{* * *}$ & 3.081 & .435 \\
\hline $.093 * * *$ & $.158^{* * *}$ & 1.000 & $.279 * * *$ & 4.076 & 2.555 \\
\hline $.076^{* * *}$ & $.180 * * *$ & $.298^{* * *}$ & 1.000 & 21.496 & 2.317 \\
\hline 41.973 & 3.055 & 3.935 & 21.177 & & \\
\hline 17.360 & .442 & 2.557 & 2.534 & & \\
\hline
\end{tabular}

